\title{
Examining conifer canopy structural complexity across forest ages and elevations with LiDAR data
}

\author{
Van R. Kane, Jonathan D. Bakker, Robert J. McGaughey, James A. Lutz, \\ Rolf F. Gersonde, and Jerry F. Franklin
}

\begin{abstract}
LiDAR measurements of canopy structure can be used to classify forest stands into structural stages to study spatial patterns of canopy structure, identify habitat, or plan management actions. A key assumption in this process is that differences in canopy structure based on forest age and elevation are consistent with predictions from models of stand development. Three LiDAR metrics (95th percentile height, rumple, and canopy density) were computed for 59 secondary and 35 primary forest plots in the Pacific Northwest, USA. Hierarchical clustering identified two precanopy closure classes, two low-complexity postcanopy closure classes, and four high-complexity postcanopy closure classes. Forest development models suggest that secondary plots should be characterized by low-complexity classes and primary plots characterized by high-complexity classes. While the most and least complex classes largely confirmed this relationship, intermediate-complexity classes were unexpectedly composed of both secondary and primary forest types. Complexity classes were not associated with elevation, except that primary Tsuga mertensiana (Bong.) Carrière (mountain hemlock) plots were complex. These results suggest that canopy structure does not develop in a linear fashion and emphasize the importance of measuring structural conditions rather than relying on development models to estimate structural complexity across forested landscapes.
\end{abstract}

Résumé : Des mesures LiDAR de la structure de la canopée peuvent être utilisées pour classifier les peuplements forestiers sur la base de leur stade structural dans le but d'étudier les patrons spatiaux de la structure de la canopée, d'identifier des habitats ou de planifier des activités d'aménagement. Une hypothèse clé de ce processus est que les différences structurales de la canopée basées sur l'âge de la forêt et sur l'altitude sont cohérentes avec les prévisions des modèles de développement des peuplements. Trois variables dérivées du LiDAR (hauteur du $95^{\text {ième }}$ percentile, complexité de la structure horizontale et densité de la canopée) ont été calculées pour 59 parcelles de forêt secondaire et 35 parcelles de forêt primaire de la région du nord-ouest du Pacifique, aux États-Unis. Un regroupement hiérarchique a identifié deux classes avant la fermeture de la canopée, deux classes de faible complexité après la fermeture de la canopée et quatre classes de forte complexité après la fermeture de la canopée. Les modèles de développement forestier indiquent que les parcelles de forêt secondaire devraient être caractérisées par des classes de faible complexité alors que les parcelles de forêt primaire devraient être caractérisées par des classes de forte complexité. Bien que les classes les plus et les moins complexes confirment largement cette relation, les classes de complexité intermédiaire, contrairement aux attentes, étaient composées de types forestiers secondaires et primaires. Les classes de complexité n'étaient pas associées à l'altitude, sauf dans le cas des parcelles de forêt primaire de Tsuga mertensiana (Bong.) Carr. (pruche subalpine) qui étaient complexes. Ces résultats indiquent que la structure de la canopée ne se développe pas de façon linéaire et soulignent l'importance de mesurer les conditions structurales plutôt que de s'en remettre aux modèles de développement pour estimer la complexité structurale des paysages forestiers.

[Traduit par la Rédaction]

\section{Introduction}

Structure is a fundamental attribute of forest ecosystems. The three-dimensional arrangement of trees and crowns reflects a forest's historical development, provides habitat, and influences ecological functions (Spies 1998; McElhinny et al. 2005). However, our understanding of forest structure may have been limited in some important ways by the cost of traditional field measurements. Most studies of forest structure are based on relatively few plots that are often subjectively selected (e.g., Spies and Franklin 1991; Van Pelt and Nadkarni 2004). Models of forest structural dynamics suggest that a very large number of forest structural states are possible (Smith and Urban 1988), raising the possibility that even 200-300 plots may not adequately sample the range of variation present. The sizes of plots also limit the

Received 4 August 2009. Accepted 3 March 2010. Published on the NRC Research Press Web site at cjfr.nrc.ca on 19 April 2010.

V.R. Kane, ${ }^{1}$ J.D. Bakker, J.A. Lutz, and J.F. Franklin. School of Forest Resources, College of the Environment, University of Washington, Box 352100, Seattle, WA 98195, USA.

R.J. McGaughey. Pacific Northwest Research Station, USDA Forest Service, University of Washington, Box 352100, Seattle, WA, 98195, USA.

R.F. Gersonde. Watershed Services Division, Seattle Public Utilities, 19901 Cedar Falls Road SE, North Bend, WA 98045, USA.

${ }^{1}$ Corresponding author (e-mail: vkane@u.washington.edu). 
ability to study spatial patterns of structural complexity at stand to landscape scales.

Airborne LiDAR can address these issues by measuring forest areas that contain the equivalent of tens to hundreds of thousands of plots. LiDAR produces high-resolution measurements of forest canopy structure over large areas (Wulder et al. 2008). However, if LiDAR-derived maps of forest structure are to further our understanding of forest development, we need to understand how canopy structure measured by LiDAR relates to overall stand development. Previous studies have shown a high correlation between LiDAR measurements of canopies and traditional field measurements of forest structure (e.g., Næsset 2002). Kane et al. (2010) found that the rankings of stand structural complexity produced using traditional field measurements of live tree structure were highly correlated with the rankings produced using LiDAR measurements of canopy structure. Therefore, LiDAR data provide information about some aspects of forest structural complexity equivalent to that obtained from field measurements. By extension, it should be possible to use LiDAR to improve our understanding of the ways forest structure changes over time by studying large samples of forest area.

This conjecture assumes that forest complexity follows sequential development paths (e.g., stand initiation, stem exclusion, understory reinitiation, and old growth) (Oliver and Larson 1996). On the other hand, forests are known to follow multiple pathways of development (Frelich and Reich 1995; Chen and Popadiouk 2002; Kint et al. 2004). LiDAR measurements of large forest expanses would be expected to include stands that followed different paths to reach their current states and would include stands that represent structural conditions and age combinations not expected from linear models of forest development.

As a result, comparing LiDAR measurements of canopy structure across a diverse set of field plots with the conditions predicted by stand development models is an important step before using LiDAR to classify forests across large expanses. Conversely, inventorying forest structure with LiDAR may suggest new classes of forest structure and help enrich models of stand development and assign structural conditions to different pathways of development. Such studies also could provide assessments of how commonly stands follow development paths similar to those in linear models versus multiple pathways that can lead to many structural states.

Three factors enabled us to test the relationship between LiDAR measurements of canopy structure and theories of stand development in this study. First, we had access to data from an extensive permanent sample plot network in a large watershed in the Cascade Mountains of Washington State, USA This network was laid out systematically to sample a wide variety of stand ages (19-93, 220-350, and 600 years old) across three forest vegetation zones associated with elevation ranges (Franklin and Dyrness 1988). Second, we had access to data from a nearly concurrent LiDAR acquisition that was flown over the entire study area. And third, research in the last decade has created models of canopy structural development that can be used to associate specific developmental stages with canopy attributes (Ishii et al. 2004).
The objective of this study was to test whether conifer canopy structure as measured by LiDAR demonstrated differences in structural complexity based on forest age and elevation that were consistent with the structures predicted by models of stand development for our region (Table 1). In this study, we directly classified forest structure using LiDAR-derived metrics to avoid presumptions about paths and rates of structural development. Structural classes were chosen quantitatively based on several canopy variables and were used to test two questions: (i) Could the distribution of sites between classes be explained by differences in age? Specifically, we wanted to test the hypothesis that young secondary plots (19-93 years old) would have distinct canopy structural characteristics compared with primary plots (>220 years old). (ii) Could the distribution of sites between classes be explained by differences in elevation and the associated changes in forest composition and development rates? We particularly wanted to test whether high-elevation plots would have less complex canopy structure than lowerelevation plots, paralleling their lower productivity.

\section{Materials and methods}

\section{Study area}

The study area was the 36679 ha Cedar River Municipal Watershed located on the western flanks of the Cascade Range in Washington State, USA (Fig. 1). Elevations range from 165 to $1655 \mathrm{~m}$. Forests at elevations below $800 \mathrm{~m}$ lie primarily in the Western Hemlock Zone (Franklin and Dyrness 1988; Henderson et al. 1992) and are dominated by Tsuga heterophylla (Raf.) Sarg. (western hemlock) and Pseudotsuga menziesii (Mirb.) Franco var. menziesii (Douglas-fir) with Thuja plicata Donn ex D. Don (western redcedar) as a minor constituent.

Forests at elevations from 800 to $1200 \mathrm{~m}$ lie in the Pacific Silver Fir Zone and are dominated by Abies amabilis (Dougl. ex Loud.) Dougl. ex J. Forbes (Pacific silver fir) and western hemlock with Abies procera Rehd. (noble fir) as a minor constituent. Forests above $\sim 1200 \mathrm{~m}$ lie in the Mountain Hemlock Zone and are dominated by Tsuga mertensiana (Bong.) Carrière (mountain hemlock) and Pacific silver fir. All three zones are dominated by conifers, although deciduous trees and shrubs are present at generally low abundances.

The majority of the watershed's forests (84\%) are second growth $<100$ years old that established naturally (pre-1930s) or were planted following harvest (Erckmann et al. 2000). Timber harvests began in the western lowlands of the watershed in the early 20th century and moved eastward into higher elevations until harvest ceased in the 1990s. As a result, second-growth stand ages are correlated with elevation and forest zone. Less than $1 \%$ of the watershed is 100200 years old; no stands in that age range were included in this study. A portion of the watershed (16\%), primarily at mid- to high elevations, consists of primary forests 200350 years old that appear to have regenerated following widespread stand-replacing disturbances, presumably fires (Hemstrom and Franklin 1982; J.A. Henderson, Pacific Northwest Research Station, USDA Forest Service, personal communication (2009)). Forests in one basin survived these 
Table 1. Common relationships of physical structural elements with stand development stages (Spies and Franklin 1991; Lertzman et al. 1996; Franklin et al. 2002; Ishii and McDowell 2002; Van Pelt and Nadkarni 2004; Van Pelt and Sillett 2008) and ages for forests in the Western Hemlock Zone (Franklin and Dyrness 1988).

\begin{tabular}{|c|c|c|}
\hline $\begin{array}{l}\text { Stages and classes identi- } \\
\text { fied in this study }\end{array}$ & Stem characteristics of canopy trees & Canopy characteristics \\
\hline $\begin{array}{l}\text { Establishment to canopy } \\
\text { closure (0-30 years), } \\
\text { classes } 1 \text { and } 2\end{array}$ & $\begin{array}{l}\text { Stems have small diameters. Varies widely be- } \\
\text { tween sites in duration and sapling density, } \\
\text { although density is often high }\end{array}$ & $\begin{array}{l}\text { Trees initially are short and have long crowns that } \\
\text { have not expanded laterally to fill the space be- } \\
\text { tween trees. Canopy closure occurs when tree } \\
\text { crowns occupy all two-dimensional growing space } \\
\text { and a nearly continuous canopy is created }\end{array}$ \\
\hline $\begin{array}{l}\text { Biomass accumulation/ } \\
\text { competitive exclusion } \\
\text { (30-80 years), classes } 3 \\
\text { and } 4\end{array}$ & $\begin{array}{l}\text { Trees add biomass at high rate. May include } \\
\text { significant competitive mortality in densely } \\
\text { stocked stands. Variation in stem diameters } \\
\text { increases, as competitive trees grow more } \\
\text { quickly than noncompetitive trees. Stem } \\
\text { density decreases due to mortality }\end{array}$ & $\begin{array}{l}\text { Tree density is high and subdominant trees die from } \\
\text { competitive exclusion with survivors filling in the } \\
\text { canopy space that becomes available. Canopy } \\
\text { structures are typically homogeneous with limited } \\
\text { vertical or horizontal diversity and few canopy } \\
\text { gaps. Crown heights rise with height growth and } \\
\text { loss of shaded foliage in the lower section of the } \\
\text { canopy }\end{array}$ \\
\hline $\begin{array}{l}\text { Mature ( } 80-200 \text { years), } \\
\text { class } 6\end{array}$ & $\begin{array}{l}\text { Continued growth of trees as they approach } \\
\text { full height. Variation in tree diameter be- } \\
\text { comes more pronounced. Establishment of } \\
\text { shade-tolerant tree cohorts common. Mortal- } \\
\text { ity of canopy trees increasingly caused by } \\
\text { disturbance (e.g., disease, insects, and wind- } \\
\text { throw) rather than competition }\end{array}$ & $\begin{array}{l}\text { Individual tree mortality due to disturbances rather } \\
\text { than competition begins to create greater structural } \\
\text { diversity in the canopy. Mortality often is spatially } \\
\text { aggregated, creating canopy variation and gaps at } \\
\text { the one- to several-tree-width scales. Individual } \\
\text { trees begin to develop variation in vertical distri- } \\
\text { bution of their canopies and foliage begins to oc- } \\
\text { cupy a larger portion of the bole length where } \\
\text { epicormic sprouting occurs along the stem }\end{array}$ \\
\hline $\begin{array}{l}\text { Vertical diversification } \\
(200+\text { years }) \text {, classes } 5 \\
7, \text { and } 8\end{array}$ & $\begin{array}{l}\text { Stem density of canopy trees increases as new } \\
\text { cohort of shade tolerant trees reaches the ca- } \\
\text { nopy. Emergence of new canopy cohort may } \\
\text { cause mean diameter of canopy trees to de- } \\
\text { cline, while variation in canopy tree dia- } \\
\text { meters increases. Top breakage and } \\
\text { emergence of shade-tolerant trees can lower } \\
\text { mean tree height }\end{array}$ & $\begin{array}{l}\text { Shade-tolerant trees that established under the ca- } \\
\text { nopy grow to fill gaps. Considerable variation de- } \\
\text { velops in the geometric complexity of the exposed } \\
\text { outer canopy surface due to variation in heights } \\
\text { and widths of canopy trees and variation in the } \\
\text { vertical distribution of foliage on older trees. Ca- } \\
\text { nopy gaps become larger and more common }\end{array}$ \\
\hline
\end{tabular}

Note: Typical age ranges for Western Hemlock Zone are shown. Development patterns are believed to be similar in the Pacific Silver Fir and Mountain Hemlock Zones, but the time needed to progress from one stage to another typically is longer in those zones. The horizontal diversification stage (Franklin et al. 2002) is not included because it can only be measured at spatial scales larger than those used in this study.

disturbances and have a cohort of trees $\sim 600$ years old interspersed among younger cohorts.

\section{Field data}

Our study used existing data from an established a network of 115 permanent sample plots. The locations of field sites were based on a randomly placed hexagonal network, with a small number of sites hand selected to increase sample size of primary forests heterogeneity. Plots were relocated to alternative network points if a primary plot location fell on stand edges or included a road or major stream. These criteria lead to homogeneity in stand development stages within each field site while systematically sampling the diversity of forest types and developmental stages present in the study area.

Field data were collected from 2003 to 2005, with most sampling done in the summer and early fall. Twenty-one plots were eliminated from this study because of missing data or because (since this is a study of conifer stands) deciduous trees comprised $>5 \%$ of the basal area. Of the 94 plots that were used in this study, 59 are second-growth forest and 35 are primary forest (Fig. 2). Sites were predominately in the Western Hemlock and Pacific Silver Fir Zones with a few sites in the Mountain Hemlock Zone.
The stand age for each plot was estimated in the field by taking an increment core at breast height of a sample of dominant trees within the plot, counting tree rings to the pith of the core, and assigning the age of the oldest trees to the site. All secondary forest sites were aged, but only 11 of the 35 primary forest plots were aged. Forest ages were further verified with historic harvest and regeneration maps of the watershed management.

Field plot radius was chosen to include $>25$ live trees with diameter at breast height $(\mathrm{DBH})>12.7 \mathrm{~cm}$. Plots ranged from 0.04 to 0.16 ha with a mean of 0.10 ha and a mode of 0.08 ha (59\% of plots). The location of each plot center was determined using a Trimble Pathfinder Pro XRS GPS System and recorded on a TSC1 Asset Surveyor. The data were postprocessed using Trimble Pathfinder software to remove satellite position distortion.

Trees were classified as dominant, codominant, intermediate, or overtopped, based on relative crown size and position within the canopy, according to Kraft's Crown Classification (Smith et al. 1997). Only data from dominant, codominant, and intermediate trees were included in this study. These trees would have crowns that extended into the overstory canopy surface and therefore would have had been measured by LiDAR. Canopy cover was measured as the mean of 16 
Fig. 1. Shaded relief map of the Cedar River Municipal Watershed in Washington State, USA $\left(47.4^{\circ} \mathrm{N}, 121.9^{\circ} \mathrm{W}\right)$, showing dominant forest zones and locations of sample plots. Plots are coded as primary (circle) or secondary (triangle) forest and by structural class (classes $1-8$; see Fig. 3).

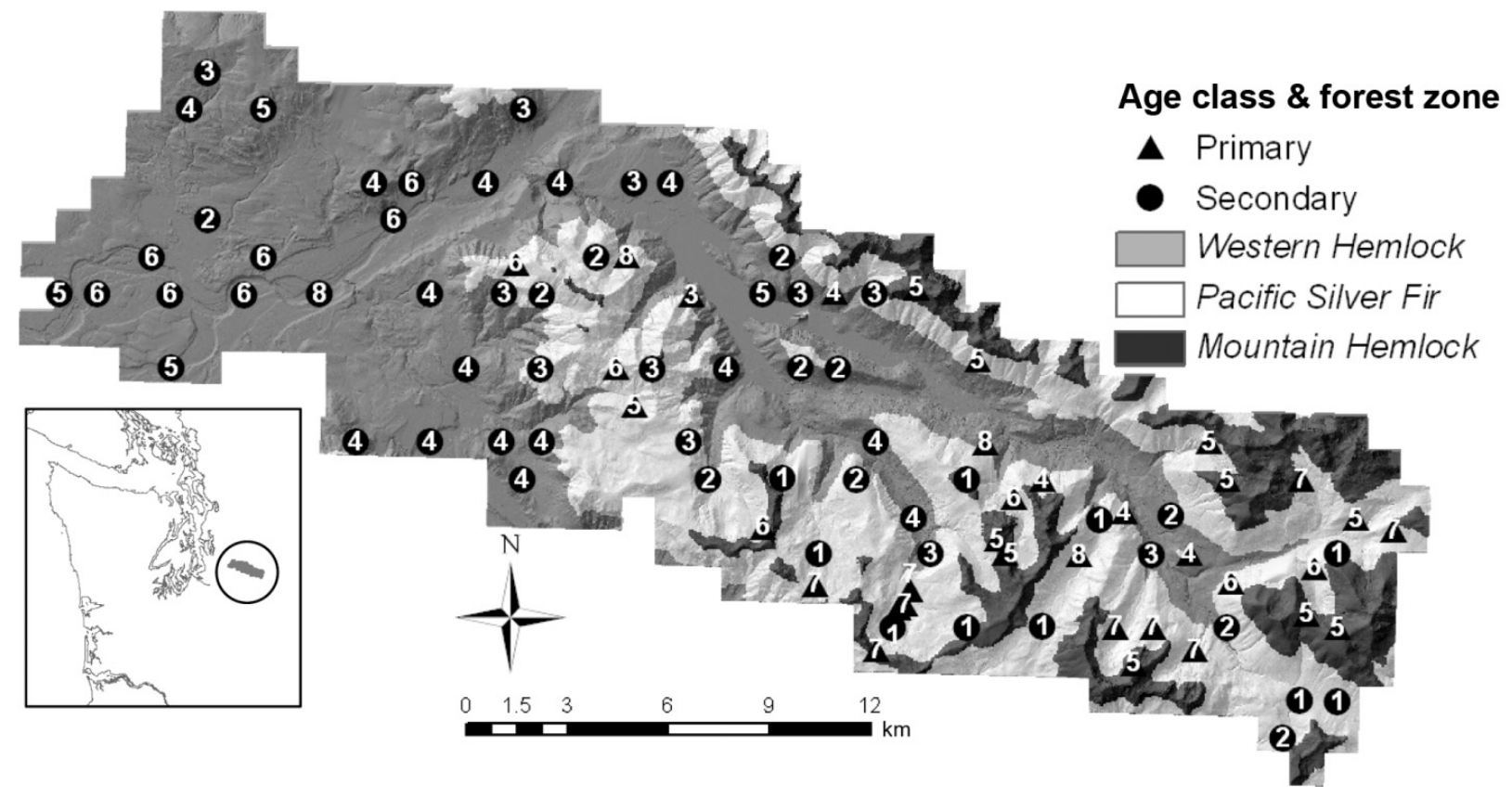

Fig. 2. Histograms showing plot characteristics for site age and elevation. Broken lines show approximate lower elevations for the Pacific Silver Fir (800 m) and Mountain Hemlock (1200 m) Zones.

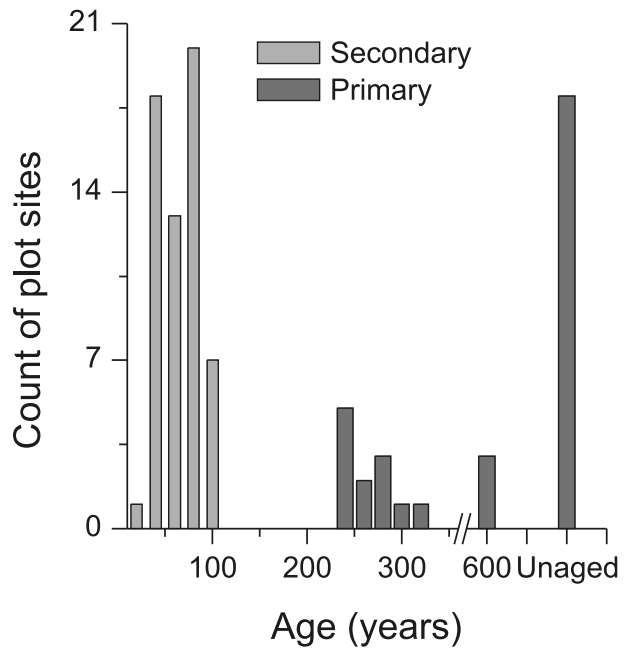

canopy closure measurements taken using a spherical densiometer at four points along each of four lines radiating from the plot center in each cardinal direction.

Primary forest fragments are present in the Western Hemlock Zone in small, scattered patches across the study area. The systematic grid pattern of sample plots poorly sampled these patches with just four plots in the data set. With such a small sample, the question arose whether they are representative of primary Western Hemlock Zone stands as a whole. To address this question, additional canopy samples were selected from 15 primary forest fragments for LiDAR data analysis. Because eight years had passed since the collection of the LiDAR data, we could no longer do field work that would be contemporary with the LiDAR data. We did not

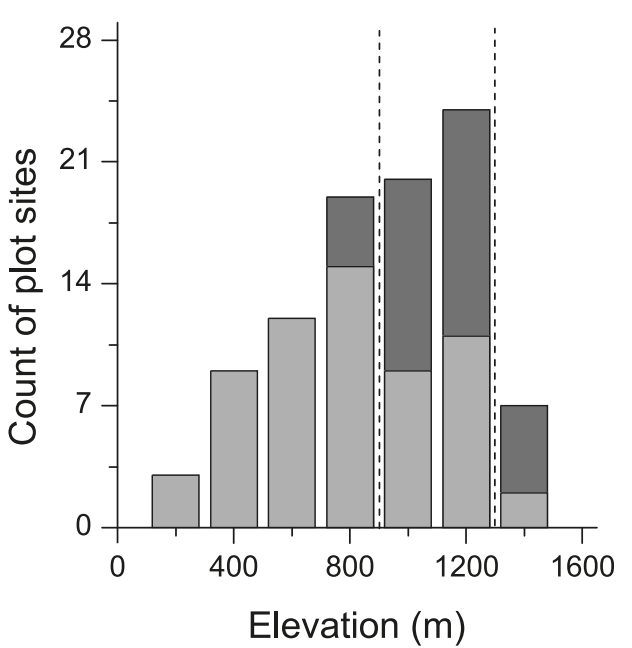

integrate these additional sites into the full study but used them only to assess whether the field plots were representative of primary Western Hemlock Zone stands in general.

\section{LiDAR data}

LiDAR data were collected by Spectrum Mapping, LLC using their DATIS II system during leaf-off conditions over the winter of 2002-2003. Nominal flying height above ground for the LiDAR acquisition was $2000 \mathrm{~m}$. Data were captured with a laser pulse repetition rate of $35 \mathrm{hHz}$, a scan rate of $25 \mathrm{~Hz}$, a scan angle of $\pm 13.5^{\circ}$, a ground footprint diameter of $0.46 \mathrm{~m}$, and an average laser pulse spacing of $1.0 \mathrm{~m}$ across track and $2.0 \mathrm{~m}$ along track. Up to five returns were recorded for each pulse. Swath centerline spacing was 
$400 \mathrm{~m}$ with an approximate overlap of $50 \%$ between adjacent flight lines. Pulse (first return) point density for study plots ranged from 0.4 to $2.7 \mathrm{~m}^{-2}$ (mean $=0.97 \mathrm{~m}^{-2}$ ). The proportion of pulses without multiple returns ranged from 0.59 to $1.0($ mean $=0.85)$. The multiple return densities varied by stand type and geographic location within the watershed. To ensure that variation in multiple return proportions did not affect the results, only the first return LiDAR data were used for calculating canopy structure metrics. As a result, only trees with exposed crown surfaces (i.e., dominant, codominant, and intermediate trees) were likely to be represented in the LiDAR data.

LiDAR data were processed using the FUSION software package (beta version derived from version 2.64; http:// forsys.cfr.washington.edu/fusion.html) (McGaughey 2009). Processing methods were identical to those of Kane et al. (2010) and are summarized here. A $3 \mathrm{~m}$ resolution digital terrain model was created from all returns in the LiDAR point cloud using an iterative algorithm over the entire watershed. For each plot, the subset ("clip") of LiDAR first returns in a $30 \mathrm{~m} \times 30 \mathrm{~m}(0.09 \mathrm{ha})$ square centered on the recorded GPS location was created. Canopy heights were calculated by subtracting the elevation of the underlying digital terrain model from each first return. The 0.09 ha size approximated the most common plot size and better correlated with field measurements than clip sizes that varied in size to match plot sizes (Kane et al. 2010). Canopy surface models were created from each elevation-normalized LiDAR subset using a $1.5 \mathrm{~m}$ grid cell and a $3 \times 3$ smoothing algorithm in which the average value of the nine cells of a moving window was assigned to each grid cell. Smoothing was used to produce a high-resolution canopy surface model given the relatively low-density LiDAR data.

\section{LiDAR metrics}

Kane et al. (2010) identified a suite of three LiDAR metrics, 95th percentile height, canopy density, and rumple, as having equivalent explanatory power and strong correlation with a suite of common field metrics of live tree structure: mean diameter at breast height (DBH), standard deviation (SD) of DBH, density of canopy trees, density of trees of $>100 \mathrm{~cm} \mathrm{DBH}$, and canopy closure. The 95th percentile height metric was calculated directly from the point cloud centered on each study site using all first return heights in the LiDAR clip. Canopy density is strongly correlated with field measurements of canopy closure (Kane et al. 2010). Canopy density was calculated as the proportion of first returns $>3 \mathrm{~m}$ in height divided by the total number of first returns and measures the proportion of area in which foliage blocked the view of the ground or low growing vegetation from the LiDAR instrument. Rumple is a measure of the rugosity of the canopy surface and is the ratio of the canopy surface area divided by the underlying ground surface ratio. First introduced by Parker et al. (2004), rumple is correlated with stand structure and age (Kane et al. 2008). Rumple was computed using the canopy surface model grid points to create a triangular irregular network of three-dimensional points, summing the area of all triangles, and dividing by the underlying ground surface area. While the vertical (onedimensional) structural heterogeneity of tree height can be quantified using metrics such as SD of heights, rumple is a three-dimensional measurement of heterogeneity (Kane et al. 2010). The surface area of conifer crowns typically increases with tree height, causing rumple also to increase with increasing tree height. (Similarly, SD of height also tends to increase with tree height.) Rumple therefore should be interpreted in light of canopy height. For example, a rumple value of 2.5 for a $30 \mathrm{~m}$ 95th percentile height would indicate high structural complexity, while the same rumple for a $60 \mathrm{~m}$ height would indicate low structural complexity.

\section{Statistical analysis}

As a basis for understanding multivariate relationships between plots, we initially explored the relationship between individual metrics and stand age through regressions of site age and both LiDAR and field metrics data (unaged primary plots were not included in regressions). We considered all plots together and the primary and secondary forest plots separately. Regressions were performed with the SigmaPlot software package (version 9) (Systat Software, Inc., San Jose, California).

The three LiDAR metrics were then used to classify plots into structural classes. To increase confidence that the identified classes were not an artifact of the statistical method used, we used two independent methods, hierarchical clustering and discriminant analysis (McCune and Grace 2002), to classify plots. The final choice of the number of classes was based on balancing intragroup homogeneity, the number of groups, and ecological interpretability (McCune and Grace 2002). Hierarchical clustering defines classes by grouping the most similar observations in a hierarchical fashion (Legendre and Legendre 1998) and was conducted using the hclust function in the $\mathrm{R}$ statistical package (release 2.6.1) (R Development Core Team 2007) with Euclidean distances and Ward's linkage method (McCune and Grace 2002). Discriminant analysis creates eigenvectors that maximize separation between previously identified groups (McCune and Grace 2002) and was conducted with the lda function of the MASS package (version 7.2-41) in R (Venables and Ripley 2002).

Relationships among classes were explored using scatterplots and principal components analysis (PCA). PCA was appropriate for these data, as most variables had approximately linear relationships with each other (McCune and Grace 2002). PCA was conducted with the prcomp function of the R statistical package (release 2.6.1) (R Development Core Team 2007). All variables were normalized prior to PCA analysis to eliminate differences in scale and units of measurement among variables.

\section{Results}

\section{Classification of canopy structure}

Based on the results of the hierarchical clustering analysis, we identified eight classes (Fig. 3). The proportion of sites assigned to the same class with hierarchical clustering and discriminant analysis was 0.99 for eight classes. The number of plots per class ranged from 5 to 19 sites (mean = 11.8). Classes with characteristics of more complex canopies such has taller crowns, greater rumple, and either denser canopies (precanopy closure) or a larger proportion of can- 
Fig. 3. Dendrogram showing eight classes resulting from a hierarchical clustering based on three LiDAR metrics (95th percentile height, rumple, and canopy density). Variance explained shows statistical distance between groups of plots. Numbers below the dendrogram identify the canopy structural classes referred to in this study.

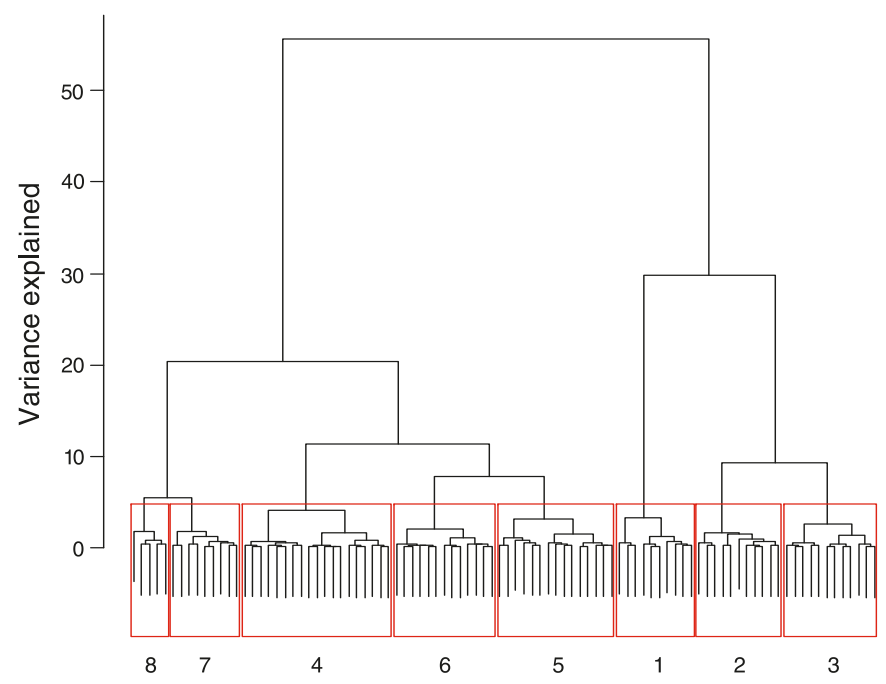

opy gaps (postcanopy closure) were assigned higher class numbers (Table 2; Fig. 4).

The greatest statistical distance found by hierarchical clustering was between classes 1-3 and all other classes and then between classes 4-6 and classes 7 and 8. Classes 7 and 8 had the smallest statistical difference among groups. Compared with the other groups of classes, classes 1-3 had short canopies, low rumple values, and the widest range of canopy density values. In contrast, classes 7 and 8 had the highest 95th percentile heights, highest rumple values, and canopy density values from 0.68 to 0.94 . Classes $4-6$ had intermediate values.

The classes formed distinct clusters in both the PCA ordination (Fig. 5) and the scatterplots (Fig. 6). Because 95.9\% of the variance in the ordination was explained in the first two axes, only these axes are presented and interpreted. The ordination showed a distinct V-shaped pattern. "Arch" patterns can sometimes occur as artifacts with community data (McCune and Grace 2002), but this pattern was an inherent characteristic of these data (Kane et al. 2010). One arm of the "V" featured sites $<50$ years old, with a trend of increasing height and canopy density (Fig. 5). The other arm included sites $>75$ years old, with a trend of increasing rumple and decreasing canopy density (Fig. 5). Sites 50-75 years old were predominantly at the base of the "V".

The primary forest plots in the Western Hemlock Zone showed a wide range of values for height, rumple, and canopy density; two sites were assigned to class 8 and two to class 4 . This wide range of values was also found in the additional 15 LiDAR-only primary Western Hemlock Zone sites selected to determine if the variation in Western Hemlock Zone plots were representative of stands in this zone (Figs. 6 and 7).

\section{Relationships between canopy structure and forest age}

Relationships of individual measures of structure with for- est age differed for secondary and primary forest plots, but for all measures, considerable overlap existed between ranges for secondary and primary sites (Fig. 8). For secondary forests, 95th percentile height, mean height, rumple, $\mathrm{SD}$ of height, and canopy density showed significant linear relationships with stand age $\left(R^{2}=0.23-0.85\right.$, all $\left.p<0.001\right)$. No significant relationships were found for aged primary sites. Canopy closure (canopy density $>0.7$ ) was observed for most plots older than the 30-50 year age class. Primary sites and secondary sites $>50$ years old had canopy densities between 0.68 and 1.0.

Some broad relationships were found between the eight classes and site age, but numerous exceptions were found to these trends (Fig. 9a). Classes 3-6 and 8 included both primary and secondary plots, classes 1 and 2 had only secondary plots, and class 7 had only primary plots. Sites 1969 years old were predominately in classes 1-4 (90\%), while sites 70-93 years old were $60 \%$ in classes $1-4$ and were $40 \%$ in classes $5-8$. Primary sites were predominantly in classes 5-8 (86\%).

\section{Relationships between canopy structure and elevation}

Few clear relationships between elevation and class were apparent (Fig. 9b). All classes included sites from both the Western Hemlock and Pacific Silver Fir Zones. The primary forest Mountain Hemlock Zone sites were only in class 6. Secondary Western Hemlock Zone sites were more common in classes with more complex structural characteristics than were secondary Pacific Silver Fir Zone sites. However, this trend could not be separated from the harvest history that resulted in older secondary sites being predominately in the Western Hemlock Zone and younger sites being in the $\mathrm{Pa}$ cific Silver Fir Zone.

\section{Discussion}

\section{Classification of canopy structure}

We identified eight classes of canopy structure that were distinct in all statistical analyses. These classes were often not associated with specific age groups or elevation. The strong pattern in the ordination suggests that the classes represent stages in the development of forest structure, and we interpreted the classes based on canopy attributes typical of specific development stages (Table 1).

Classes 1 and 2 exhibited increasing height and canopy density with little change in rumple value. Because of their young ages $($ mean $=32.5$ years $)$, short heights $(95$ th percentile mean $=9.94 \mathrm{~m}$ ), and low canopy densities (mean = 0.55 ), we interpreted them to reflect precanopy closure conditions. In the ordination, these classes were found in the arm of the ordination arch labeled ">Closure" and appear to represent the attributes of stands progressing toward canopy closure.

All other classes were postcanopy closure (which we interpreted as canopy density $>0.7$ ). Classes 3 and 4 had 95th percentile heights that overlapped most of the height range of classes 5-8. However, classes 3 and 4 had lower rumple values (mean $=1.66$ ) and higher canopy density values (mean $=0.99)$ than classes $5-8$ (rumple mean $=2.94$, canopy density mean $=0.87$ ). In the ordination, classes 3 and 4 were found in the base of the " $\mathrm{V}$ " and appear to represent 
Table 2. LiDAR- and field-based metrics for the eight canopy structural classes defined by structural characteristics.

\begin{tabular}{|c|c|c|c|c|c|c|c|c|c|c|}
\hline \multirow[b]{2}{*}{ Class } & & \multirow[b]{2}{*}{$\begin{array}{l}\text { No. of } \\
\text { plots }\end{array}$} & \multicolumn{3}{|c|}{ LiDAR metrics } & \multicolumn{5}{|l|}{ Field metrics } \\
\hline & & & $\begin{array}{l}\text { 95th percen- } \\
\text { tile height } \\
\text { (m) }\end{array}$ & Rumple & $\begin{array}{l}\text { Canopy density } \\
\text { (proportion) }\end{array}$ & $\begin{array}{l}\text { Mean DBH } \\
(\mathrm{cm})\end{array}$ & $\begin{array}{l}\text { SD DBH } \\
(\mathrm{cm})\end{array}$ & $\begin{array}{l}\text { Canopy closure } \\
\text { (proportion) }\end{array}$ & $\begin{array}{l}\text { Density of } \\
\text { canopy } \\
\text { trees }^{\prime} \mathrm{ha}^{-1}\end{array}$ & $\begin{array}{l}\text { Density of } \\
>100 \mathrm{~cm} \mathrm{DBH} \\
\text { trees } \cdot \mathrm{ha}^{-1}\end{array}$ \\
\hline \multirow[t]{3}{*}{1} & All & 10 & $7.1(0.8)$ & $1.2(0.05)$ & $0.23(0.04)$ & $17(0.8)$ & $3(0.5)$ & $0.51(0.08)$ & $5.5(0.2)$ & $0(0)$ \\
\hline & Primary & 0 & - & - & - & - & - & - & - & - \\
\hline & Secondary & 10 & $7.1(0.8)$ & $1.2(0.05)$ & $0.23(0.04)$ & $17(0.8)$ & $3(0.5)$ & $0.51(0.08)$ & $5.5(0.2)$ & $0(0)$ \\
\hline \multirow[t]{3}{*}{2} & All & 11 & $12.5(0.9)$ & $1.3(0.05)$ & $0.76(0.02)$ & $18.7(0.9)$ & $4.6(0.6)$ & $0.73(0.06)$ & $6.2(0.2)$ & $0(0)$ \\
\hline & Primary & 0 & - & - & - & - & - & - & - & - \\
\hline & Secondary & 11 & $12.5(0.9)$ & $1.3(0.05)$ & $0.76(0.02)$ & $18.7(0.9)$ & $4.6(0.6)$ & $0.73(0.06)$ & $6.2(0.2)$ & $0(0)$ \\
\hline \multirow[t]{3}{*}{3} & All & 12 & $23.9(1.3)$ & $1.4(0.06)$ & $0.98(0.007)$ & $25.9(2.5)$ & $9(1.3)$ & $0.91(0.008)$ & $6.9(0.1)$ & $1(1)$ \\
\hline & Primary & 1 & $28(-)$ & $1.7(-)$ & $0.96(-)$ & $48.1(-)$ & $12.8(-)$ & $0.89(-)$ & $5.8(-)$ & $0(-)$ \\
\hline & Secondary & 11 & $23.6(1.3)$ & $1.4(0.06)$ & $0.98(0.007)$ & $23.9(1.7)$ & $8.7(1.4)$ & $0.91(0.008)$ & $7(0.1)$ & $1.1(1.1)$ \\
\hline \multirow[t]{3}{*}{4} & All & 19 & $39.4(1)$ & $1.8(0.05)$ & $0.97(0.005)$ & $43.4(2.5)$ & $15.6(1.1)$ & $0.89(0.009)$ & $6.1(0)$ & $6.5(4.6)$ \\
\hline & Primary & 4 & $39.2(2.1)$ & $1.8(0.14)$ & $0.95(0.01)$ & $58.5(6.6)$ & $20.2(4.7)$ & $0.9(0.02)$ & $5.9(0.1)$ & $29.5(19.5)$ \\
\hline & Secondary & 15 & $39.4(1.1)$ & $1.8(0.06)$ & $0.98(0)$ & $39.4(1.5)$ & $14.3(0.7)$ & $0.89(0.009)$ & $6.1(0)$ & $0.4(0.4)$ \\
\hline \multirow[t]{3}{*}{5} & All & 15 & $31.3(0.9)$ & $2.4(0.07)$ & $0.87(0.01)$ & $42.2(2.6)$ & $17.2(1.3)$ & $0.87(0.01)$ & $6(0)$ & $1.7(1.2)$ \\
\hline & Primary & 11 & $31(1.2)$ & $2.3(0.09)$ & $0.85(0.02)$ & $43.4(3.1)$ & $17.9(1.6)$ & $0.88(0.01)$ & $6(0)$ & $2.4(1.6)$ \\
\hline & Secondary & 4 & $31.9(1.6)$ & $2.5(0.07)$ & $0.93(0.02)$ & $39(4.8)$ & $15.3(2.6)$ & $0.84(0.04)$ & $5.8(0.2)$ & $0(0)$ \\
\hline \multirow[t]{3}{*}{6} & All & 13 & $43(0.8)$ & $2.7(0.06)$ & $0.93(0.008)$ & $44.9(3.1)$ & $18.6(1.8)$ & $0.88(0.01)$ & $5.8(0.1)$ & $5(2.4)$ \\
\hline & Primary & 6 & $43.1(1.3)$ & $2.7(0.08)$ & $0.94(0.01)$ & $52.3(5.4)$ & $23.6(2.5)$ & $0.92(0)$ & $5.7(0.2)$ & $10.8(4.1)$ \\
\hline & Secondary & 7 & $42.9(1)$ & $2.7(0.09)$ & $0.93(0)$ & $38.5(1.3)$ & $14.3(1.2)$ & $0.85(0.019)$ & $5.9(0)$ & $0(0)$ \\
\hline \multirow[t]{3}{*}{7} & All & 9 & $38.7(0.9)$ & $3.3(0.1)$ & $0.77(0.02)$ & $54.3(1.5)$ & $28.7(2.3)$ & $0.88(0.01)$ & $5.3(0)$ & $18.3(6.1)$ \\
\hline & Primary & 9 & $38.7(0.9)$ & $3.3(0.1)$ & $0.77(0.02)$ & $54.3(1.5)$ & $28.7(2.3)$ & $0.88(0.01)$ & $5.3(0)$ & $18.3(6.1)$ \\
\hline & Secondary & 0 & - & - & - & - & - & - & - & - \\
\hline \multirow[t]{3}{*}{8} & All & 5 & $51.3(3.3)$ & $4.1(0.08)$ & $0.86(0.03)$ & $62.8(3)$ & $35.3(7.7)$ & $0.86(0.01)$ & $5.2(0.1)$ & 30.4 (13) \\
\hline & Primary & 4 & $52.1(4.1)$ & $4.2(0.07)$ & $0.8(0.03)$ & $64.1(3.5)$ & $39.3(8.5)$ & $0.87(0.02)$ & $5.1(0.1)$ & 38 (13.6) \\
\hline & Secondary & 1 & $47.8(-)$ & $3.9(-)$ & $0.9(-)$ & $57.9(-)$ & $19.2(-)$ & $0.84(-)$ & $5.2(-)$ & $0(-)$ \\
\hline
\end{tabular}

Note: Because age group (primary and secondary) was not used in defining classes, different proportions of primary versus secondary sites by class represent differences in frequency that plots in these age groups have the associated structural attributes of a class within our sample of sites. Data are shown for all plots and separately for primary and secondary forests. Values are means (SE). Values for field metrics are for dominant, codominant, and intermediate canopy class trees only. 
Fig. 4. Examples of canopy surface models of plot sites included in this study. Numbers above canopy images are structural class designations (Fig. 3). Higher numbers indicate more complex canopies based on greater 95th percentile heights, rumple values, and lower canopy density values (Table 1). Canopy surface model images are for fixed-size plots $(30 \mathrm{~m} \times 30 \mathrm{~m})$ and horizontal and vertical scales are the same. Means and SEs of field- and LiDAR-based metrics for each class are presented in Table 2.

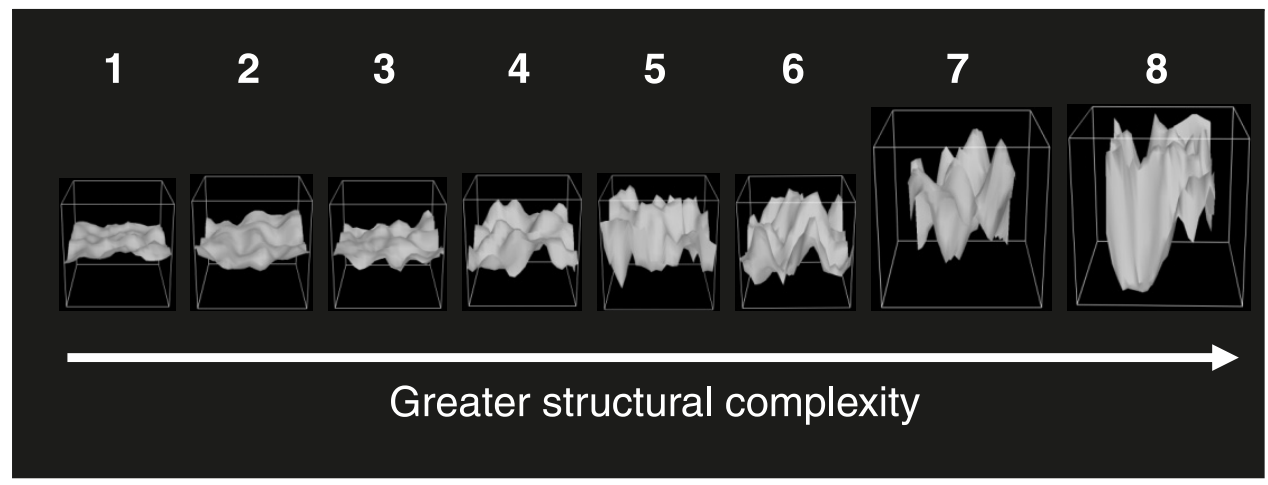

Fig. 5. Ordination resulting from principal components analysis of LiDAR metrics for plots. LiDAR density is the canopy density computed from LiDAR data. Class and age code for each plot are shown. The length of each arrow indicates the strength of the correlation between that variable and the axes. Angles between arrows indicate the strength of the correlation between the metrics (smaller angles $<90^{\circ}$ indicate higher positive correlations, $90^{\circ}$ angles are uncorrelated, $>90^{\circ}$ angles are negatively correlated, and $180^{\circ}$ angles are perfectly negatively correlated). The bottom and left axes (coordinate system 1) are the principal components (actual observations matrix multiplied by loadings), while the top and right axes (coordinate system 2) are the loadings ("weights" assigned to each variable after centering and scaling).

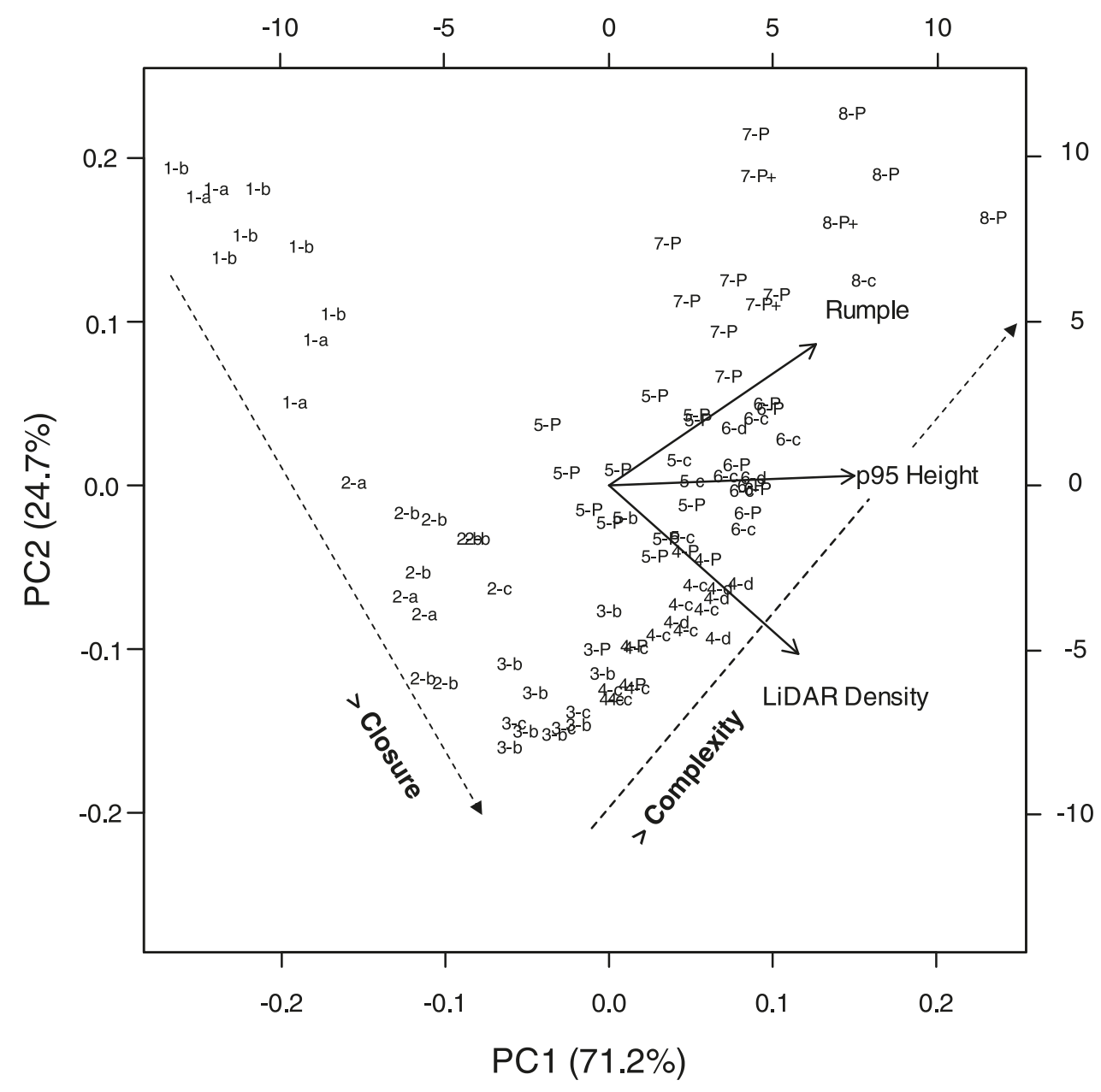

Age class codes (years): a: <30; b: 30-54; c: 55-80; d: 80-93; P: 220-350; P+: 600 
Fig. 6. Relationship between 95th percentile height and rumple values (upper panels) and canopy density values (lower panels). Plots are coded by canopy structural class (leftmost panels) and separately by forest zone (remaining panels).

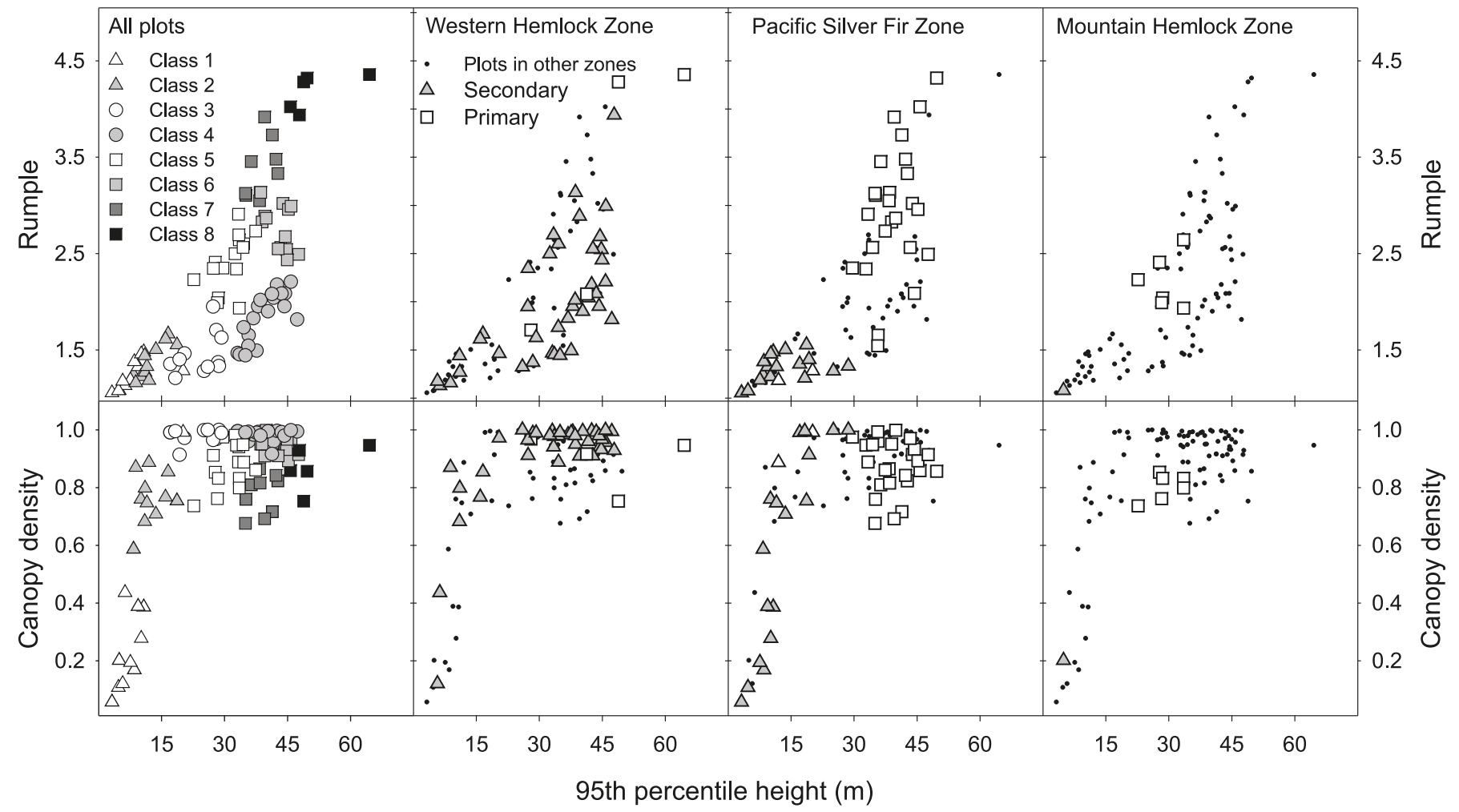

homogenous canopy structure typical of the biomass accumulation/competitive exclusion stages. Classes 5-8 were found in the arm labeled ">Complexity" and appear to represent the increase of tructural heterogeneity and canopy layering and the creation of canopy gaps typical of the maturation and vertical diversification stages. Based on these observations, we interpreted classes 3 and 4 as lower complexity and classes 5 to 8 as higher complexity closed-canopy classes. Overall, classification of forest canopy structure through LiDAR metrics allowed us to distinguish forest development stages based on the effect of predominant processes on structural attributes.

\section{Relationships between canopy structure and forest age}

We had expected a clear differentiation of secondary and primary forests given the $>130$-year age gap between them. Instead, the structural characteristics of these groups overlapped. This overlap was not an artifact of the LiDAR metrics used in this study; these plots also overlapped in ordinations based on field metrics (Kane et al. 2010). Values for individual field and LiDAR metrics also overlapped between the primary and secondary sites.

We expected that many of our classes, which were defined solely on structural attributes without reference to age, would have few if any members of one of the age groups (primary versus secondary). For example, we expected that there would be no primary plots in classes $1-3$, which represent structural characteristics of sites in early establishment through early canopy closure. The surprise was that one primary site was found in class 3. Similar expectations were held for the structural classes 7 and 8 associated with old- growth characteristics. The surprise was that there was one secondary stand in these classes. One important result from this study was that five of eight groups contained a mixture of primary and secondary stands, indicating that stand age is insufficient for a a complete understanding of structural stage.

The overlap of age groups across classes suggests either multiple pathways of structural development, great variability in timing of structural development (Harper et al. 2003), or dynamics due to different site conditions or species replacements (Chen and Popadiouk 2002). Linear models of forest development suggest that canopy complexity increases with age (Oliver and Larson 1996). If so, 95th percentile height and rumple should increase with age; canopy density should decrease with age following initial canopy closure. Our results correspond well for young and old forest plots but not in the intermediate classes.

Stand structural complexity develops at variable rates for forests in our study area (Larson et al. 2008). While the timing of transitions from one structural class to another cannot be predicted for individual sites, the general trend is of increasing complexity with age. Since the difference between the lower complexity classes 3 and 4 and the higher complexity classes 5-8 was observed in rumple and canopy density values, we infer that the development of structurally complex canopies is independent of height growth. Possible causes for this observation are explored in the following sections.

\section{Relationships between canopy structure and elevation}

Forests in three elevation-driven composition zones exam- 
Fig. 7. Comparison of canopy structural characteristics for Western Hemlock Zone plots for which there were both field and LiDAR data with an additional 15 primary sites for which there were LiDAR data only. The wide range of values for the 15 additional sites suggest that the range of values for the four primary plot sites were characteristic of primary sites in this forest zone.

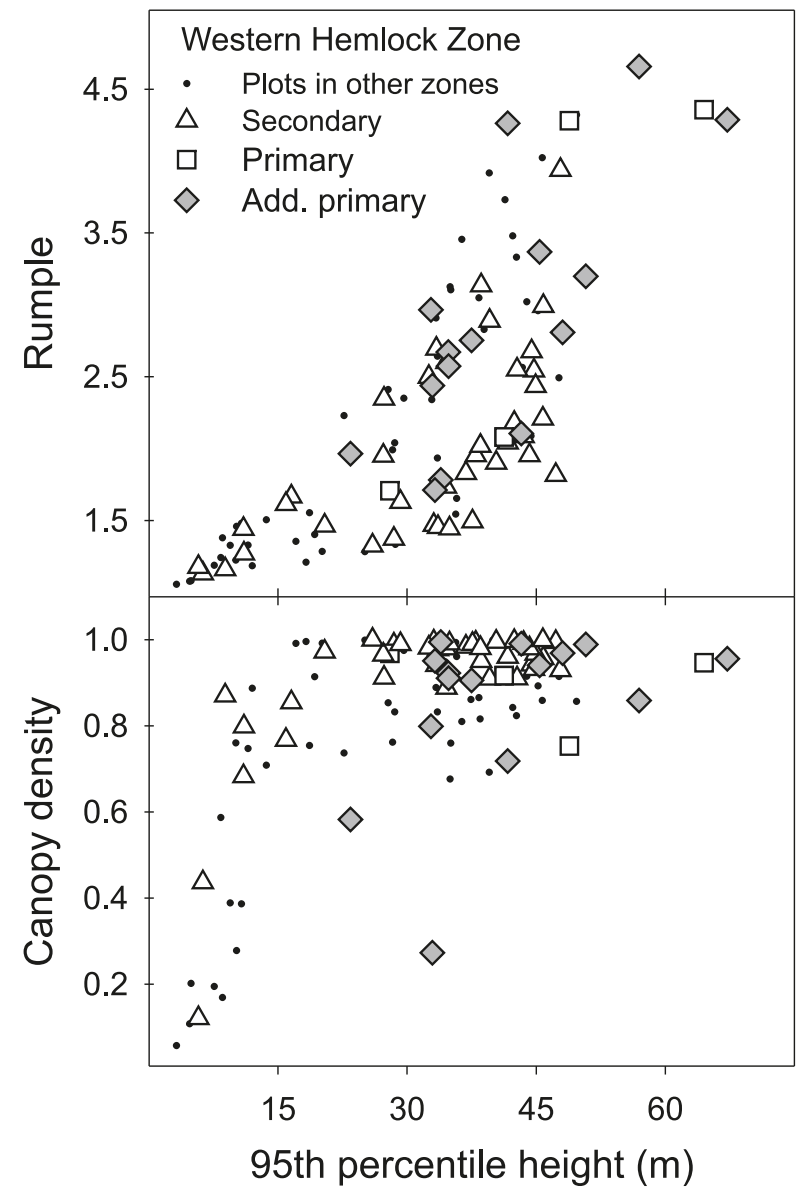

ined in this study are thought to follow similar patterns of structural development following stand-replacing disturbance, although they differ in temporal scales for developing structural complexity (Spies and Franklin 1991; Larson and Franklin 2006; Parish and Antos 2006). Timing differences would suggest that canopy complexity should vary among forest zones given the management history in the watershed.

Early seral stands in the Western Hemlock Zone are frequently dominated by Douglas-fir, which exhibits rapid height growth on favorable growing sites. Associated shadetolerant species such as western redcedar and western hemlock grow more slowly and have shorter heights at maturity; they can be present from stand initiation (Larson and Franklin 2006; Lutz and Halpern 2006) or can establish later and subsequently dominate late in stand development. The competitive exclusion period in this zone typically lasts $\sim 50$ years (Franklin et al. 2002). Disturbance agents include periodic wind disturbance, bark beetles, and root pathogens.

Mature stands in the Pacific Silver Fir and Mountain Hemlock Zones are often dominated by western hemlock and Pacific silver fir and generally do not reach the same heights and crown dimensions as in the Western Hemlock Zone, although early seral stands dominated by noble fir can reach substantial heights. The competitive exclusion stage in this zone can extend for 100-300 years (Packee et al. 1982) due to the predominance of shade-tolerant species. Root pathogens play an important role as small-scale disturbance in late seral stages (Lertzman and Krebs 1991) in these zones, as do abiotic factors such as snow. Structural development in the highest-elevation Mountain Hemlock Zone is even slower due to environmental conditions, with competitive exclusion continuing for centuries (Parish and Antos 2006) and prolonged periods of recovery from disturbance.

Based on these considerations, canopy structural complexity might be expected to develop most quickly in the Western Hemlock Zone where growth and disturbance rates are highest and more slowly in the Mountain Hemlock Zone. In our data set, comparisons between forest zones can be made only for primary forest sites (secondary sites in the Western Hemlock and Pacific Silver Fir Zones had little age overlap and there was only one Mountain Hemlock Zone secondary site). As expected, the primary sites with the highest 95th percentile heights and greatest rumple values (class 8) belonged primarily to the Western Hemlock Zone, although two Pacific Silver Fir Zone sites were also in this class. The dominance of Western Hemlock Zone sites in class 8 would likely have been more pronounced if there were more primary forest plots in this zone. This result is consistent with the greater growth potential and more frequent disturbances expected in the Western Hemlock Zone.

Field visits to the three 600-year-old Pacific Silver Fir Zone sites showed that many dominant trees had broken tops, thus reducing canopy height and rumple. If the dominant trees had remained intact, it is probable that the two 600 -year-old sites classified as class 7 would have instead been classified as class 8 ; one other 600 -year-old site was classified as class 8). This suggests that considerable age might be needed for many Pacific Silver Fir Zone sites to achieve maximum canopy structural complexity, although one 271-year-old plot in the Pacific Silver Fir Zone site achieved class 8 complexity.

The primary sites of the Western Hemlock and Pacific Silver Fir Zones were present in both high- (classes 5-8) and low-complexity (class 4) postcanopy closure classes. No clear pattern of greater structural complexity for Western Hemlock Zone sites was apparent except in class 8. If more primary Western Hemlock Zone field plots had been available, the wide range of structural conditions for this zone likely would have been more pronounced. The forces creating canopy structure across these two forest zones may have more in common than an examination of published growth rates and disturbance patterns would suggest. All of the primary Mountain Hemlock Zone sites fell into class 5. This class has the lowest heights and rumple values of the higher-complexity classes. This result was in accordance with expectations based on growth rate and disturbance patterns for this zone.

\section{Explanations for variation observed}

Current models of the development of canopy structure in temperate and boreal forests of North America are based on studies of relatively few sites (Frelich and Reich 1995; Lertzman et al. 1996; Harper et al. 2003) compared with 
Fig. 8. Relationship of LiDAR metrics (left panels) and field metrics (right panels) with forest age. Significant linear relationships with age $(p<0.001)$ were found for all secondary forest plots. No significant linear relationships were found for aged primary plot sites. Unaged primary forest sites were not included in regressions but are plotted to allow comparisons.

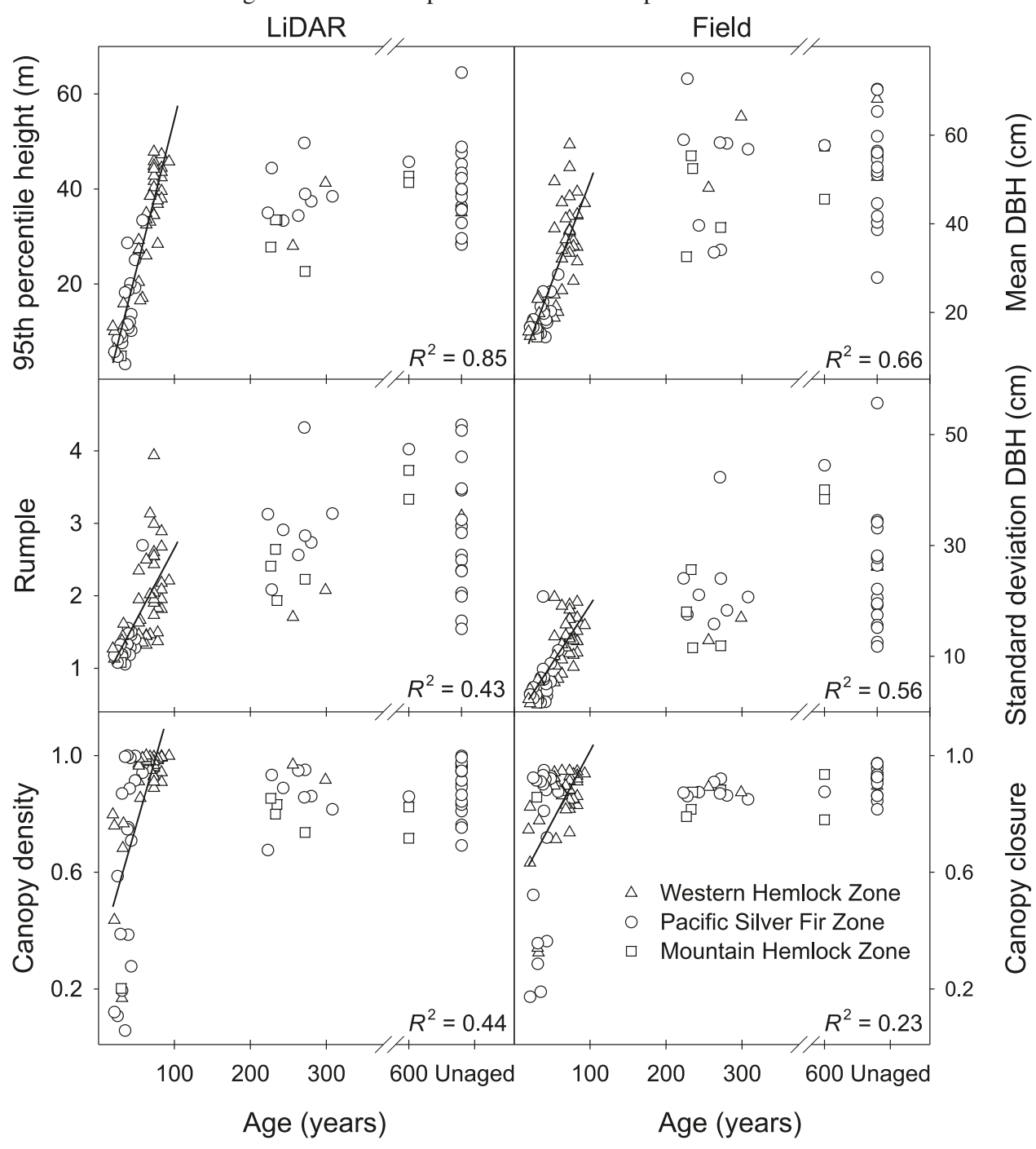

Fig. 9. Distribution of $(a)$ stand ages and $(b)$ elevations among structural classes. Unaged plots were primary forests assumed to be >220 years old. Broken lines show approximate lower elevations for the Pacific Silver Fir (800 m) and Mountain Hemlock (1200 m) Zones.

a) Age

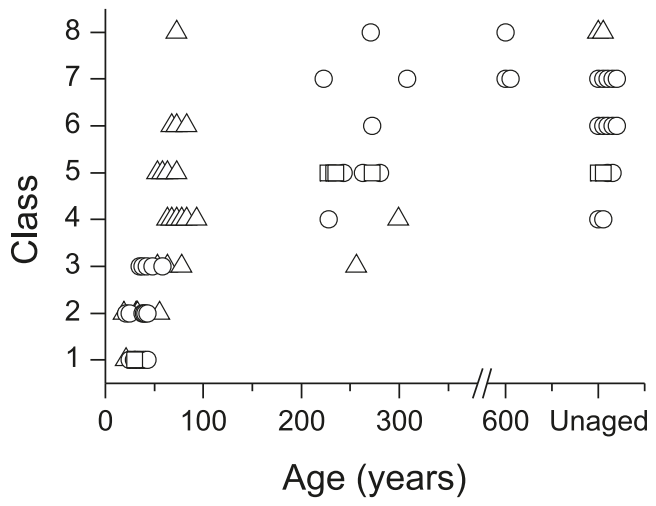

$\triangle$ Western Hemlock Zone

$\bigcirc$ Pacific Silver Fir Zone

Mountain Hemlock Zone b)

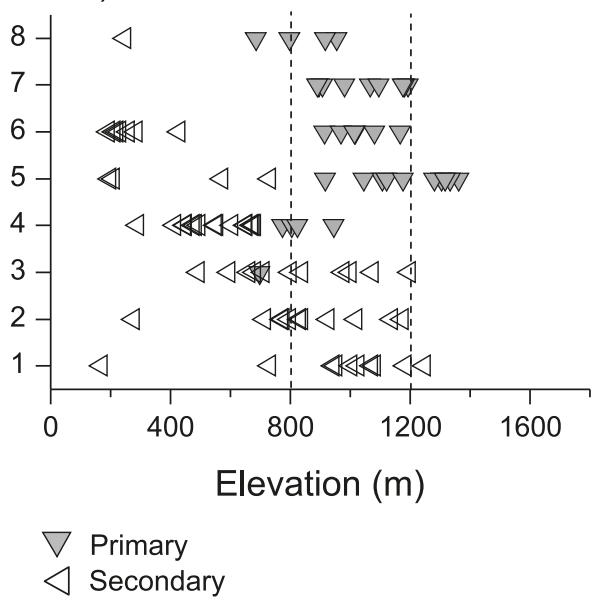


the variety of structural conditions possible. These models postulate that, after canopies close, stands become more complex with time. However, models of structural development are typically qualified by statements that considerable variation exists around the general trend of increasing structural complexity with age (Franklin et al. 2002; Harper et al. 2003), and multiple pathways of development have been proposed for forests in our study region (USDA Forest Service 2003). Our analysis found unexpectedly high variation in structure both within and among age groups, supporting the concept of multiple development pathways over sequential development models.

Two aspects of our study methods might explain a portion of the variation observed in our study. Many studies exploring structural development seek archetypical sites (e.g., Spies and Franklin 1991; Van Pelt and Nadkarni 2004), which will tend to reinforce differences between structural stages. In contrast, the systematic grid used to establish our plots was designed to sample a wide variety of stand conditions across a large watershed, thus increasing heterogeneity within our sample of plots. Second, stands frequently contain considerable heterogeneity. This heterogeneity is commonly accounted for in field studies by using the mean and standard deviation (or standard error) from several randomly placed plots to represent stand characteristics. This study sampled a wide variety of stands, but with a single representative plot in each. Our results may therefore highlight within-stand variability.

Ecological theory also provides considerable explanation for the overlap of canopy structural complexity in primary and secondary forests and between elevations. Factors that increase structural development at some secondary sites and retard structural development at some primary sites include differences in establishment conditions and site productivity and the presence of intermediate disturbances subsequent to stand establishment.

Reforestation practices during the 80 years of timber harvest in the watershed evolved from a reliance on natural regeneration to intensive artificial reforestation. These changes would be associated with differences in initial conditions due to variation in the amount of soil scarification, site modification by slash burning, residual seedlings and mature trees, and the nature of any reseeding or replanting. Older stands that include our 70- to 96-year-old plots were left to reseed naturally or were replanted when the practice was new to the region and not carefully managed for quality. Also, fires caused by railroad logging activities were common in the pre-World War II era and this reburning may have prolonged the establishment period, leading to greater heterogeneity between plots during early stand development. Variation in the time needed to establish the initial tree cohort can lead to variation in subsequent tree size and density (Tappeiner et al. 1997; Winter et al. 2002).

Other establishment conditions could lead to homogeneity in canopy structure. Shade-tolerant species such as Pacific silver fir and western hemlock can recruit at high densities and experience little competitive mortality for many decades. If a cohort of trees grows under homogeneous site conditions (light, water, and nutrients) and experiences few intermediate disturbances, it may develop a very even canopy with low rumple values. Intermediate disturbance may also trigger a dense cohort of regeneration beneath an existing canopy. When this cohort achieves a codominant position, it can reduce heterogeneity in the canopy (Van Pelt and Franklin 2000). The modern regeneration harvest methods and silvicultural techniques used post-1930 also should have resulted in greater homogeneity in stands younger than 70 years (Oliver and Larson 1996).

Differences in site productivity also could explain a portion of the variation. The development of stand structure has been shown to progress faster on more productive sites (Harper et al. 2002; Larson et al. 2008). Differences in soils and aspect may account for some of the variation found within our study. However, the most obvious correlates of growth potential, elevation and associated growing season length (Lutz et al. 2010), were not associated with class for either the Western Hemlock Zone or the Pacific Silver Fir Zone. In the mountainous terrain of our study area, multiple forest zones lie in close proximity to each other and their transition appears gradual in nature. This observation supports the common practice in the Pacific Northwest to conduct studies across multiple elevation ranges, with sites hundreds of kilometres apart and spanning $>1000 \mathrm{~m}$ in elevation. Such studies have examined disturbance patterns (Spies et al. 1990; Lertzman et al. 1996), forest development (Spies and Franklin 1991), and the relationship of LiDAR measurements to forest structure (Lefsky et al. 2005).

The presence or absence of intermediate disturbance offers another explanation for the variation observed. Recent work (Weisberg 2004; Zenner 2005) has found that young stands that had experienced partial disturbance can be more complex structurally than stands considerably older that had not experienced partial disturbance. Conversely, primary forest sites that had not experienced partial disturbance could fail to develop structural complexity and could resemble much younger stands.

Traditionally, partial disturbance has been viewed as uncommon for stands $<80$ years old, and studies focusing on small-scale disturbance have ignored younger stands (Spies et al. 1990; Lertzman et al. 1996). However, in one developing young stand $(<38$ years old) in the Oregon Cascades, mechanical damage (from wind, snow, or ice or combinations of these agents) was important in creating aggregated patches of mortality that accounted for $80 \%$ of the biomass loss in the stand (Lutz and Halpern 2006). Watershed managers have documented windthrow damage and crown damage in young forests from periodic wind events (R.F. Gersonde, unpublished data) that are common in the western central Cascades. Periodic small-scale wind disturbance could reduce stand density at an early age and result in greater rumple and lower canopy density. Root rot (principally Phellinus weirii) can severely reduce densities in young $P$. menziesii stands within two decades (Hansen and Goheen 2000). These observations suggest that disturbance may be a more important agent of structural development in second-growth forests than is commonly assumed and could result in a wide range of canopy structural complexities depending on the chance occurrence or absence of disturbance.

These same disturbance agents should also operate on primary forests, and intermediate disturbance is cited as a primary driver of structural development for these stands (Franklin et al. 2002). However, disturbance is by definition 
stochastic and should occur unevenly across a landscape. Our primary plots with low-complexity canopies may be sites that simply have failed to experience intermediate disturbance.

\section{Conclusions and implications for future research}

We conclude that canopy structural complexity structure does not develop in a fashion that can be linearly related to forest age or with elevation range. These results fit expectations from models of multiple pathways of forest succession or at least widely varying rates of development among sites within age and elevation ranges. If these results are confirmed by future studies, then forest classifications based on linear models of forest succession may prove difficult.

However, our results suggest new directions for future research. LiDAR data can be used to stratify structural conditions across a range of forest ages, site productivities, and geomorphologies. This information could then be used to select field plots with which to examine questions about how differences in canopy structure relate to variation in developmental pathways, structural attributes that cannot be readily measured with LiDAR such as understory diversity, processes such as carbon cycling, and biodiversity.

Alternatively, the classification methods presented here can be used to study larger spatial patterns of canopy structure either to elucidate ecological processes or to better inform management actions. For example, classification of forest structural conditions across large areas is critical for the assessment of forest habitat using habitat relationship models. Current models typically rely on inventory-based information of forest structure (Johnson and O'Neil 2001). Future work could extend our approach and link canopy structure to habitat relationship models applied over large areas (Richards et al. 2002). The wide range of variation in canopy complexity found within and across age ranges emphasizes the importance of measuring structural conditions rather than relying on stand age and linear models of structural development to estimate structural complexity.

\section{Acknowledgements}

This work was supported by NASA Headquarters under the NASA Earth and Space Science Fellowship Program (grant NNX07AN75H). The Watershed Services Division of Seattle Public Utilities, the King County Government of Washington State, and the Nature Conservancy of Washington State provided funding support. The Watershed Services Division of Seattle Public Utilities shared their permanent plot data and the LiDAR data used in the study. Comments by Derek Churchill, James A. Freund, Charles Halpern, R. Keala Hagmann, Andrew J. Larson, Christian Torgersen, and two anonymous reviewers improved earlier drafts of this manuscript.

\section{References}

Chen, H.Y.H., and Popadiouk, R.V. 2002. Dynamics of North American boreal mixedwoods. Environ. Rev. 10(3): 137-166. doi:10.1139/a02-007.

Erckmann, J., Chinn, A., Flagor, S., Kurko, K., Freeman, J., Little, R., Schneider, G., and Vanderhoof, J. 2000. Final Cedar River Watershed Habitat Conservation Plan. City of Seattle, Seattle, Wash. Available from www.seattle.gov/util/About_SPU/
Water_System/Habitat_Conservation_Plan/AbouttheHCP/ Documents/index.htm.

Franklin, J.F., and Dyrness, C.T. 1988. Natural Vegetation of Oregon and Washington. Oregon State University Press, Corvallis, Ore.

Franklin, J.F., Spies, T.A., Van Pelt, R., Carey, A.B., Thornburgh, D.A., Berg, D.R., Lindenmayer, D.B., Harmon, M.E., Keeton, W.S., Shaw, D.C., Bible, K., and Chen, J.Q. 2002. Disturbances and structural development of natural forest ecosystems with silvicultural implications, using Douglas-fir forests as an example. For. Ecol. Manag. 155(1-3): 399-423. doi:10.1016/S03781127(01)00575-8.

Frelich, L.E., and Reich, P.B. 1995. Spatial patterns and succession in a Minnesota southern-boreal forest. Ecol. Monogr. 65(3): 325-346. doi:10.2307/2937063.

Hansen, E.M., and Goheen, E.M. 2000. Phellinus weirii and other native root pathogens as determinants of forest structure and process in western North America. Annu. Rev. Phytopathol. 38(1): 515-539. doi:10.1146/annurev.phyto.38.1.515. PMID: 11701853 .

Harper, K.A., Bergeron, Y., Gauthier, S., and Drapeau, P. 2002. Post-fire development of canopy structure and composition in black spruce forests of Abitibi, Quebec: a landscape scale study. Silva Fenn. 36(1): 249-263.

Harper, K.B., Boudreault, C., DeGrandpre, L., Drapeau, P., Gauthier, S., and Bergeron, Y. 2003. Structure, composition, and diversity of old-growth black spruce boreal forest of the Clay Belt region in Quebec and Ontario. Environ. Rev. 11(Suppl. 1): S79-S98. doi:10.1139/a03-013.

Hemstrom, M.A., and Franklin, J.F. 1982. Fire and other disturbances of the forests in Mount Rainier National Park. Quat. Res. 18(1): 32-51. doi:10.1016/0033-5894(82)90020-5.

Henderson, J.A., Lesher, R.D., Peter, D.H., and Shaw, D.C. 1992. Field guide to the forested plant associations of the Mt. BakerSnoqualmie National For. Tech. Pap. R6 ECOL TP 028-91. U.S. Department of Agriculture Forest Service, Pacific Northwest Research Station.

Ishii, H., and McDowell, N. 2002. Age-related development of crown structure in coastal Douglas-fir trees. For. Ecol. Manag. 169(3): 257-270. doi:10.1016/S0378-1127(01)00751-4.

Ishii, H.T., Van Pelt, R., Parker, G.G., and Nadkarni, N.M. 2004. Age-related development of canopy structure and its ccological functions. In Forest canopies. Edited by M.D. Lowman and H.B. Rinker. Elsevier Academic Press, Burlington, Mass.

Johnson, D.H., and O'Neil, T.A. 2001. Wildlife-habitat relationships in Oregon and Washington. Oregon State University Press, Corvallis, Ore.

Kane, V.R., Gillespie, A.R., McGaughey, R., Lutz, J.A., Ceder, K., and Franklin, J.F. 2008. Interpretation and topographic compensation of conifer canopy self-shadowing. Remote Sens. Environ. 112(10): 3820-3832. doi:10.1016/j.rse.2008.06.001.

Kane, V.R., McGaughey, R.J., Bakker, J.D., Gersonde, R.F., Lutz, J.A., and Franklin, J.F. 2010. Comparisons between field- and LiDAR-based measures of stand structural complexity. Can. J. For. Res. 40(4): 761-773. doi:10.1139/X10-024.

Kint, V., Mohren, G.M.J., Geudens, G., De Wulf, R., and Lust, N. 2004. Pathways of stand development in ageing Pinus sylvestris forests. J. Veg. Sci. 15(4): 549-560.

Larson, J.A., and Franklin, J.F. 2006. Structural segregation and scales of spatial dependency in Abies amabilis forests. J. Veg. Sci. 17(4): 489-498.

Larson, A.J., Lutz, J.A., Gersonde, R.F., Franklin, J.F., and Hietpas, F.F. 2008. Potential site productivity influences the rate of forest structural development. Ecol. Appl. 18(4): 899-910. doi:10. 1890/07-1191.1. PMID:18536251. 
Lefsky, M.A., Hudak, A.T., Cohen, W.B., and Acker, S.A. 2005. Geographic variability in lidar predictions of forest stand structure in the Pacific Northwest. Remote Sens. Environ. 95(4): 532-548. doi:10.1016/j.rse.2005.01.010.

Legendre, P., and Legendre, L. 1998. Numerical ecology. 2nd English edition. Elsevier Science BV, Amsterdam, The Netherlands.

Lertzman, K.P., and Krebs, C.J. 1991. Gap-phase structure of a sub-alpine old-growth forest. Can. J. For. Res. 21(12): 17301741. doi:10.1139/x91-239.

Lertzman, K.P., Sutherland, G.D., Inselberg, A., and Saunders, S.C. 1996. Canopy gaps and the landscape mosaic in a coastal temperate rain forest. Ecology, 77(4): 1254-1270. doi:10.2307/ 2265594.

Lutz, J.A., and Halpern, C.B. 2006. Tree mortality during early forest development: a long-term study of rates, causes, and consequences. Ecol. Monogr. 76(2): 257-275. doi:10.1890/00129615(2006)076[0257:TMDEFD]2.0.CO;2.

Lutz, J.A., van Wagtendonk, J.W., and Franklin, J.F. 2010. Climatic water deficit, tree species ranges, and climate change in Yosemite National Park. J. Biogeogr. In press. doi:10.1111/j. 1365-2699.2009.02268.x.

McCune, B., and Grace, J.B. 2002. Analysis of ecological communities. MjM Software Design, Gleneden Beach, Ore.

McElhinny, C., Gibbons, P., Brack, C., and Bauhus, J. 2005. Forest and woodland stand structural complexity: Its definition and measurement. For. Ecol. Manag. 218(1-3): 1-24. doi:10.1016/j. foreco.2005.08.034.

McGaughey, R.J. 2009. FUSION/LDV: software for LIDAR data analysis and visualization. Available from http://forsys.cfr. washington.edu/fusion/FUSION_manual.pdf [last accessed July 2009].

Næsset, E. 2002. Predicting forest stand characteristics with airborne scanning laser using a practical two-stage procedure and field data. Remote Sens. Environ. 80(1): 88-99. doi:10.1016/ S0034-4257(01)00290-5.

Oliver, C.D., and Larson, B.C. 1996. Forest stand dynamics. Updated edition. John Wiley \& Sons, New York.

Packee, E.C., Oliver, C.D., and Crawford, P.D. (Editors). 1982. Ecology of Pacific silver fir. Institute of Forest Resources Contribution No. 45. College of Forest Resources, University of Washington, Seattle, Wash.

Parish, R., and Antos, J.A. 2006. Slow growth, long-lived trees, and minimal disturbance characterize the dynamics of an ancient, montane forest in coastal British Columbia. Can. J. For. Res. 36(11): 2826-2838. doi:10.1139/X06-166.

Parker, G.G., Harmon, M.E., Lefsky, M.A., Chen, J., Van Pelt, R., Weis, S.B., Thomas, S.C., Winner, W.E., Shaw, D.C., and Franklin, J.F. 2004. Three-dimensional structure of an oldgrowth Pseudotsuga-Tsuga canopy and its implications for radiation balance, microclimate, and gas exchange. Ecosystems (N.Y., Print), 7(5): 440-453. doi:10.1007/s10021-004-0136-5.

R Development Core Team. 2007. R: a language and environment for statistical computing. Available from www.R-project.org.
Richards, W.H., Wallin, D.O., and Schumaker, N.H. 2002. An analysis of late-seral forest connectivity in western Oregon, USA. Conserv. Biol. 16(5): 1409-1421. doi:10.1046/j.1523-1739. 2002.01433.x.

Smith, D.M., Larson, B.C., Kelty, M.J., and Ashton, P.M.S. 1997. The practice of silviculture: applied forest ecology. John Wiley \& Sons, New York.

Smith, T.M., and Urban, D.L. 1988. Scale and resolution of forest structural pattern. Vegetatio, 74(2-3): 143-150. doi:10.1007/ BF00044739.

Spies, T.A. 1998. Forest structure: a key to the ecosystem. Northwest Sci. 72: 34-39.

Spies, T.A., and Franklin, J.F. 1991. The structure of natural young, mature, and old-growth Douglas-fir forests in Oregon and Washington. In Wildlife and vegetation of unmanaged Douglas-fir forests. Edited by L.F. Ruggiero, K.B. Aubry, A.B. Carey, and M.H. Huff. U.S. For. Serv. Gen. Tech. Rep. PNWGTR-285. pp. 91-109.

Spies, T.A., Franklin, J.F., and Klopsch, M. 1990. Canopy gaps in Douglas-fir forests of the Cascade Mountains. Can. J. For. Res. 20(5): 649-658. doi:10.1139/x90-087.

Tappeiner, J.C., Huffman, D., Marshall, D., Spies, T.A., and Bailey, J.D. 1997. Density, ages, and growth rates in old-growth and young-growth forests in coastal Oregon. Can. J. For. Res. 27(5): 638-648. doi:10.1139/cjfr-27-5-638.

USDA Forest Service. 2003. New findings about old-growth forests. PNW-Science Update, Issue 4. USDA Forest Service, Portland, Ore.

Van Pelt, R., and Franklin, J.F. 2000. Influence of canopy structure on the understory environment in tall, old-growth, conifer forests. Can. J. For. Res. 30(8): 1231-1245. doi:10.1139/cjfr-30-81231.

Van Pelt, R., and Nadkarni, N.M. 2004. Development of canopy structure in Pseudotsuga menziesii forests in the southern Washington Cascades. For. Sci. 50(3): 326-341.

Van Pelt, R., and Sillett, S.C. 2008. Crown development of coastal Pseudotsuga menziesii, including a conceptual model for tall conifers. Ecol. Monogr. 78(2): 283-311. doi:10.1890/07-0158.1.

Venables, W.N., and Ripley, B.D. 2002. Modern applied statistics with S. 4th ed. Springer, New York.

Weisberg, P.J. 2004. Importance of non-stand-replacing fire for development of forest structure in the Pacific Northwest, USA. For. Sci. 50(2): 245-258.

Winter, L.E., Brubaker, L.B., Franklin, J.F., Miller, E.A., and DeWitt, D.Q. 2002. Initiation of an old-growth Douglas-fir stand in the Pacific Northwest: a reconstruction from tree-ring records. Can. J. For. Res. 32(6): 1039-1056. doi:10.1139/x02-031.

Wulder, M.A., Bater, C.W., Coops, N.C., Hilker, T., and White, J.C. 2008. The role of LiDAR in sustainable forest management. For. Chron. 84(6): 807-826.

Zenner, E.K. 2005. Development of tree size distributions in Douglas-fir forests under differing disturbance regimes. Ecol. Appl. 15(2): 701-714. doi:10.1890/04-0150. 